\title{
当科における特発性顔面神経麻痺の保存的治療法 一一ステロイト大量投与法の効果について——
}

\author{
山形大学医学部耳鼻咽喉科学教室（主任：小池吉郎教授） \\ 稲村博雄, 戸島均, 斎藤修, 前山裕之, 武田一彦 \\ 青 柳優, 小池吉 郎
}

CONSERVATIVE TREATMENT OF IDIOPATHIC FACIAL PALSY

- EFFECTS OF THE ADMINISTRATION OF HIGH-DOSE STEROIDS IN BELL'S PALSY

\author{
HIROO INAMURA, M.D., HITOSHI TOJIMA, M.D., OSAMU SAITO, M.D. \\ HIROYUKI MAEYAMA, M.D., KAZUHIKO TAKEDA, M.D., MASARU AOYAGI, M.D. \\ and YOSHIO KOIKE, M.D.
}

Department of Otolaryngology, Yamagata University School of Medicine, Yamagata

The etiology of Bell's palsy is still obscure and its treatment remains controversial. As a conservative treatment for Bell's palsy, Stennert developed a new treatment method for the purpose of improving microcirculation, and reported an extremely high cure rate of $96 \%$, drawing a great deal of attention. However, since the electrophysiological findings and side effects in these patients were not described satisfactorily in his report, this method has not yet come into wide clinical use.

In the present study the efficacy of Stennert's method was assessed by electrophysiological examination in patients, and was compared with patients treated by conventional methods.

The subjects of this study were 157 patients with Bell's palsy who were treated with a modification of Stennert's method between September 1987 and August 1990 . The treatment protocol for the modified Stennert's method was as follows: hydroxyethyl starch 40 with $20 \%$ mannitol is given instead of Dextran 40 and prednisolone is stopped depending on the findings of electrical examinations. Fifty-three patients with Bell's palsy treated by the conventional method used in our clinic between November 1983 and August 1987 were used for the control group. The most remarkable difference between these two methods was the initial dose of prednisolone.

In the group treated by the modified Stennert's method, 111 patients $(70.7 \%)$ showed complete recovery within 1 month, and 154 patients presented (98.1\%) showed complete recovery within 6 months, 3 cases presented slight sequelae. In the conventional treatment group, on the other hand, only 2 patients (3.8\%) recovered within 1 month, and 43 patients (81.0\%) recoverd within 6 months. The recovery rate with the modified Stennert's method was much higher than with the conventional method, and the difference was statistically significant. A comparison of the lowest value of ENoG within 2 weeks of onset revealed many cases with an ENoG value of $10 \%$ or less in the conventionally treated group (18 cases, $33.9 \%$ ), but only 9 cases (5.7\%) showed a decrease of $10 \%$ or less in the other group. These results demomstrated the efficacy of the administration of high-dose steroids.

Key words : ベル麻瘦, 保存的治療法, ステロイド大量投与, 治瘾率 A 95-0172-91575 


\section{1.はじめに}

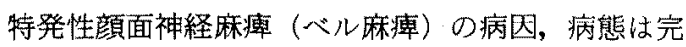
全には解明されていない。よってその治療に関しても 真に確立された方法はない，Rothendler（1951）がバ 儿麻痺治療に対するステロイドの有用性を報告して以 来”，最近ではステロイドの使用が一般的となり治痛 率も向上しているものの，不完全治癒例が約 10 数\%に 存在するのが実状であった。

1981年 Stennert はベル麻痺症例に対して, 微小循環 の改善を目的として低分子デキストラン (Dextran 40)とともに大量のステロイドを投与する保存的治療 法を行い，極めて高い治撚率を報告したが2 , 入院治療 を要することやステロイド大量使用による副作用発生 が懸念され，広く普及するには至らなかった。当科で は1983年11月より,ベル糜脾症例に詨して Stennert の 方法に準じながらもプレドニゾロン投与量を減じた保 存在治潦法を行ってきたが、゙，1987年9月からは重症 例に限定して Stennert の方法に準じた大量のステロ イド投与を行い加療を行ってきた.その結果, Stennert の報告と同様の高い治㿑率を得たものの，低分子デキ ストランによる肝機能障害が頻発したため, 点滴基剤 を Hydroxyethylstarch 40 に変更し同様のステロイ ド大量投与を行い, 肝幾能障害の発生なく有意莣ない 高い治癒率を得たことを既に報告しだ?.

本稿では，1987年 9 月より1990年 8 月までの 3 年間 に行ったステロイド大量投与療法の効果について, 治 溗率および電気生理学的検查所見上から当科における 従来の保存的治療法と比較し, 検討した。

\section{2. 対象およU゙方法}

対象は，1987年 9 月より1990年 8 月まで当科顔面神
経外来を受診したベル麻瘏321例中, 発症 7 日以内でか 一初钐時に顔面運動採点20点（日本顔面神経研究会制 定の40点法)以下のベル麻痹157例である。䍒目例，軽

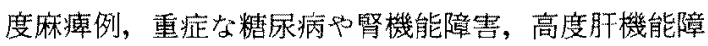
害, 胃潰浧等の重篤な合併症のある症例, 及び乳幼児, 著しい高踲者は治療対象より除いてある。これらの症 例は，全例治瘁までもしくは発症後 6 力月間まで経過 を観察し，経過観察途中での脱落症例はない。

治療は, 1988年12月までは Stennert の原法に準じて 行われ ${ }^{2]}$ 1989年 1 月からは，点滴基剂在低分子デキス トラン (Dextran 40) より Hydroxyethylstarch $40 k$ 変更し,さらにステロイドの初期投与量は同様にして 投与期間を短縮した変法により行われた（表 1，以上 Stennert 法群). 本治療法は, 原則として即日入院のう え全身状態の敩重な管理下に行い，発症 2 週を過ぎる までは頻回の Electroneurography (ENoG) を施行し て神経障害の程度を判定しつつ治療を行い, 予後良好 と判定された時点でステロイド投与を急速に減量する か中止した。治瘤の判定は, 顔面運動採点が36点以上 かつ後遺症のないものを治癒と判定した。

副作用の早期発見のため, 加療中は常に尿量, 尿比 重に注意し，十分に水補給を行い尿比重を1.050以下に 保方，また消化管潰湶の発生に十分注意し，便潜血検 查を行うと共に，必要に応じて抗潰瘭剤の投与を行っ た。糖尿病症状の出現，悪化に注意し，糖疗病患 者には頻回に血糖值を測定し必要に伈じてインスリン 使用により血糖值を管理しながら加潦した。

今回の検討の比較対照群として，1983年11月より当 科にて行っていた従来の保存的治療法を行い, 当科初 診時顔面連動採点か同様の基準をみたしたベル磨瘏53 例を採用して(表 2 , 以下従来法群)，1988年 9 月以降

表 1 特発性顔面神経麻痺保存療法（Stennert 法）

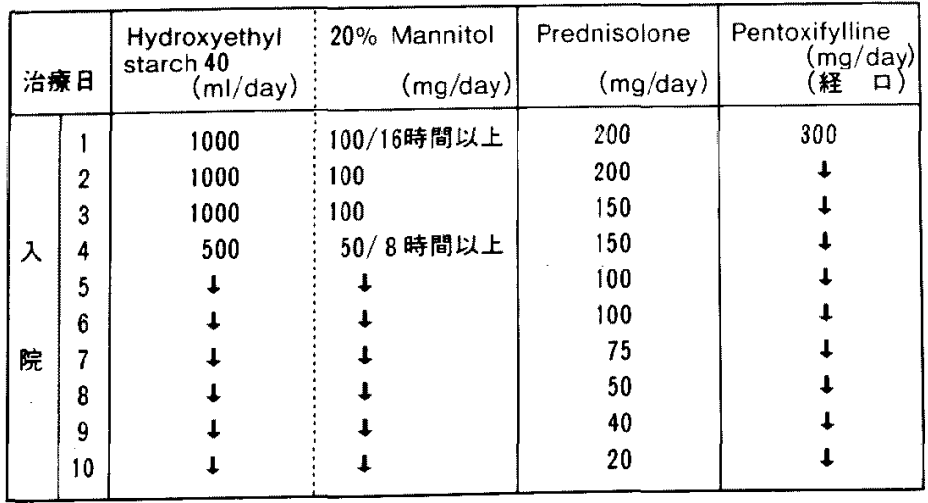


表 2 対象症例（ベル麻舫）

\begin{tabular}{lcc}
\hline & Stennert 法 & 従来法 \\
\hline 症例 & 157 & 53 \\
性 (男/女) & $85 / 72$ & $26 / 27$ \\
年齢(平均) & $12 \sim 82$ & $10 \sim 79$ \\
& $(53.4)$ & $(44.9)$ \\
\hline
\end{tabular}

表 3 両治療法の差異

\begin{tabular}{lcl}
\hline & Stennert 法 & \multicolumn{1}{c}{ 従来法 } \\
\hline 点滴基郕 & $\begin{array}{c}\text { Dextran 40 } \\
\text { (Hydroxyethyl } \\
\text { starch 40) }\end{array}$ & Hydroxyethyl \\
starch 40 \\
Prednisolone & & \\
初期投与量 & $200 \mathrm{mg} \sim$ & $60(40) \mathrm{mg} \sim$ \\
総投与量 & $550 \sim 1015 \mathrm{mg}$ & $220 \sim 145 \mathrm{mg}$ \\
\hline
\end{tabular}

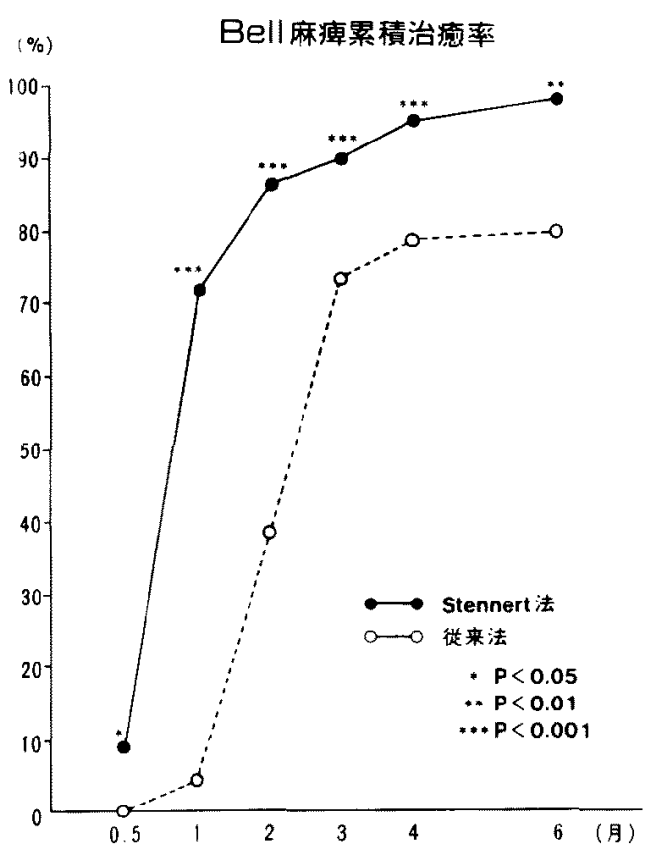

図 1 雨治療法群における発症 6 力月までの累積 治痹率

Stennert 法群は, 従来法群に比して有意に 高い治瘜率を得ている。

のステロイド大量投与を行った Stennert 法群との間 で，それぞれ発症 6 力月までの治癒率，発症 2 週以内 の ENoG 最低值につき比較検討した。両治療法群間の ステロイド投与量の差異は表 3 に示した。
表 4 ベル麻癗の治瘳率

\begin{tabular}{lccc}
\hline 顔面運動採点 & $\leqq 10$ & $\leqq 20$ & 計 \\
\hline Stennert 法 & 77 & 80 & 157 \\
(治瘾率) & $(96.1 \%)$ & $(100 \%)$ & $(98.1 \%)$ \\
従 来 法 & 12 & 41 & 53 \\
(治瘭率) & $(25.0 \%)$ & $(97.6 \%)$ & $(81.1 \%)$ \\
\hline
\end{tabular}

表 5 ENoG 分布

\begin{tabular}{cccccc}
\hline ENoG & $0 \%$ & $<10 \%$ & $<40 \%$ & $\geqq 40 \%$ & 㖕 \\
\hline Stennert 法 & 0 & 9 & 70 & 78 & 157 \\
従 来 法 & 6 & 12 & 23 & 12 & 53 \\
& $(11.3 \%)$ & $(22.6 \%)$ & $(43.5 \%)$ & $(22.6 \%)$ \\
\hline
\end{tabular}

3. 結果

i）治癒率について

Stennert 法を施行した157例中，1力月以内に111例 (77.7\%)が治癒し，6力月以内に若干の後遺症を残し た3例を除き 154 例 (98.1\%) が治癒した。これら3例 においても顔面運動採点は36点以上に至って㧍り, 病 的共同運動も極めて軽微なものであった。

一方従来法群は，1力月以内に治癒に至った症例は 53 例中 2 例 $(3.8 \%)$ のみで, 発症後 6 力月で 43 例 81.0 \%の治喻率であり, $x^{2}$ 検定にて両群間でその治癒率に 有意差を認めた（図 1)。特に初診時の顔面運動採点が 10 点以下の症例に限ると, Stennert 法群は77例中74 例，96.1\%の治瘜率であるのに対して, 従来法群では 12 例中 3 例，25\%の治瘾率であり，上り高度の麻痺を 呈した症例でそのの治癒率に大きな差を認めた（表 4).

ii ) ENoG 最低值について

発症 2 週以内の ENoG最低值を比較すると, Stennert 法群では $10 \%$ 末満となった症例はわずか 9 例で，ENoG 0\%，すな和ち完全脱神経に至った症例は 1 例もなかった。一方従来法群では，ENoG 0\%に至っ た症例が50例中 6 例（12\%）存在しまた ENoG 0\% を含めて $10 \%$ 末満に低下した症例が18例存在し，危険 率 $1 \%$ で有意に Stennert 法群が少ない結果であった (表 5).

iii） Stennert 法における副作用について

本治療において一過性の肝機能障害が20例(12.7\%) にみられたが，このうち19例は Dextran 40 使用例で あり, Hydroxyethylstarch 40 使用例では72例中わず か 1 例のみであった。便潜血出現が 8 例 $(5.0 \%)$ にみ 
られたが， $\mathrm{H}_{2}$ ブロッカー等の薬剤投与にて消失し，そ の後胃十二指腸滍瘍の治療を要した症例もなかった。 またステロイド離脱症候群 (Steroid withdrawl syndrome）を呈した症例もなく，糖尿病合併症例に対して も血糖管理を行うことにより，特に合併症を起こすこ となく治療可能であった。

\section{4. 考 察}

i）ベル麻盘における病態とステロイド大量投与 の有用性について

ベル麻㾝の病因についてはいまだ100\%は解明され て抢らず, 従来よりウイルス説点，虚血による循環障害 説 $^{(1)}$, 免疫説 ${ }^{7)}$ 等が仮説として唱えられているものの， 現在ではこ机ら諸原因により多元的な原因が考えられ るようになっている。すなわち何らかの原因により起 こった顔面神経における微小循環の障害およびそ㧈に 伴う虚血, 浮腫の進行が, ウイルス感染, 免疫反灾西 るいは疲労, 寒冷暴露などのさまざまな誘因によって 誘発されるものと考えられる。しかしながら，いった ん顔面神経管内でこれら障害が生じた後の神経変性の 進行に関しては，以下に述べるような病態が考元られ る。すなわち，顔面神経管内に生じた障害により局所 の浮腫が生じ、これが骨壁に囲まれた管の内压上昇を 来し，さらに周囲の顔面神経管よりの圧迫を受けるこ とにより末梢にまで Waller 変性が進行して行く悪循 睘が生じているのは間違いのないことであると考え る。よってベル麻痺における神経障害は, 糖尿病等の polyneuropathy に扔ける髄鞘主体の障害とは異なり， 浮腫といった間質主体の障害から生じる圧迫による compression (acute entrapment) neuropathy であ る。一般に圧迫による神経障害は太い有䯣神経線維か ら障害されていくことが知られている．また運動神経 伝導速度はその直径に比例するから，伝導速度は障害 の強さに応じて低下する。劢われが開発し臨床応用 されている顔面神経伝導速度の測定および神経伝導速

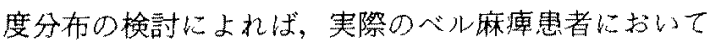
も伝導速度の速い，太い神経線維から障害㕝受けてい ることが電気生理学的に明らかになった ${ }^{819)}$.またわれ われは、実験的に顔面神経にたいして圧迫による障害 を加え，その回復過程におけるステロイドの効果を検 討したが，浮腫を軽減させ神経再生を促進するには一 定量以上のステロイド投与が有効であることをすでに 報告した ${ }^{10)}$. 顔面神経管内に扔ける障害による管内圧 の上昇抢よび浮腫の進行は, 実験的に約 1 週から 2 週
でWaller 変性の進行は最大に達し, 以後徐々に再生, 回復に向かう"11ので，この浮腫を主体とした間質の神 経障害であるべル麻痺治療に，発症早期にこれらの障 害を軽減させるに十分なる量のステロイド剂を血漿增 量剂と共に用いる本治療法は，浮腫の軽隇抢よび微小 血液循環の改善を図るに極めて合理的な治療法である と考える，今回の検討で，最終的な治撚率が向上しほ

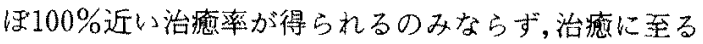
までの期間も大幅に短縮されたことは，ステロイド投 与量を大幅に増量することによりなされたと考えられ よう。特に重症例については，このステロイド大量投 与がより有効であると考えられる。

ii）電気生理学的榆查よりみたステロイド大量投 与の有用性について

従来上り顔面神経麻焷患者の予後判定には, 各種の 電気生理学的検查法が用いられてきた。しかしながら ベル麻痺等の顔面神経障害は側頭骨内の障害であるも のの日常臨床においては側頭骨外の障害を測定せる゙る を得なく, 予後判定のため正確な神経障害の程度を判 定するには, その測定手技, 湘定時期等の種々の問題 が存在している.臨床において比較的多く行われてい る検查法としては，神経興奮性検查 (Nerve Excitability test, NET), 鼠大刺激検直 (Maximal Stimulation Test, MST), 強さ一時間曲線 (Strength-Dura tion Curve, S-D Curve), Electroneurography (ENoG)等があるが，ENoG 除けば判定が肉眼に頼 り定量的ではないことや電気刺激に際してもすべての 神経線維を與奮させるものではないなどの欠点を有し ており, 神経変性の程度を単独で判定することは不可 能である. ENoGは, 特殊な機器を必要とせずにかつ 比較的簡便に施行可能で, 変性に陥つた神経線維の割 合を定量的に測定できる゙ ${ }^{121}$.すなわち，障害が physiological block の状態のとどまるうちはENoG 值は低 下しないが, axonotmesisもしくは neurotmesis の場 合は ENoG 值は低下し, 麻疸発症後約 1 週前後で最低 值に達することが明らかになっている、すなわちこの 間に経時的に本検查を行うことにより顔面神経末梢の Waller 変性進行の推移が判定可能で, 早期予後診断が ほほ正確に行うことができる.当科における検討では， ENoG 40\%以上の症例は，ほとんどが1 力月以内に治 癒し, ENoG 值が低下するほど顔面運動の回復までに 要する期間も遷延し，ENoGが10\%未満に低下した症 例では治癒, 非治癒の症例が混在して来るようになり, ENoG $0 \%$ すなわ完全脱神経に楩ると，いかなる治 
療を行っても治瘾は望めなくなる ${ }^{13)}$. ベル麻瘦の治療 に際しては, 発症早期の急性期の治療によって ENoG の低下すなわちWaller 変性の進行を阻止し, 回復に 向かわせることが最も重要であると考えられる.今回 の検討で從来法群とStennert 法群との間で発症 2 週 以内の ENoG 最低值を比較してみると, 從来法群では ENoG 0\%に至った症例が約11\%にみられ，これを含 めて ENoG が $10 \%$ 末渾の症例が約 $1 / 40$ 症例にみられ た。これに比して Stennert 法群では, 初䛦時の顔面運 動採点がより低い症例が多いにもかかわらず ENoG 0\%の症例はなく，ENoG $10 \%$ 未満の症例もかずか 9 例であり，従来法群より有意に少ない結果であつた $(\mathrm{p}<0.01)$.このように ENoGの低下すなわち神経末 梢へのWaller 変性の進行が，又テロイド投与を大幅 に増やした Stennert法により抑制されたことが本治 療法の高い治撚率をもたらしたものと考えられた。

iii）本治潦法の安全性について

本治療法に扔いてもつとも高率に見られた副作用 は，低分子デキストラン (Dextran 40) によると思わ れる ${ }^{14)}$ 肝機能障害であるが, 全症例一過性のもので, 重度障害にいたることはなかったが，1989年1月より は点滴基刜を Hydroxyethylstarch 40 に変更した。 Hydroxyethylstarch 40 は, Dextran 40 とほ活同程度 の血漿増量作用, 微小循環改善作用を有し, アナフィ ラキシーショック発生が少ない, 腎に対する安全性が 高い, 肝機能障害の発生が少ない点で優れている ${ }^{15)}$. 実 際に Hydroxyethylstarch 40 に変更後は, 肝機能障害 発生例は極めて少数となり"治療効果を損なうことな く，より安全に治療可能であることが確認された。

ステロイドの大量投与は, 脳浮腫等の脳神経外科領 域，SLEやネフローゼといった自己兔疫疾患，白血病 等の血液疾患，重症感染症等で用いられる。ステロイ ドによる副作用は多方面に及ぶが，一般に重度副作用 (major side effect) と軽度副作用 (minor side effect) に分けられる。重度副作用は, 感染の誘発增悪, 胃潰 瘍, 楉症病, 副腎機能障害, 精神症状等がある. 本治 榞法では明らかな潰淿の発生例はなかったが，約 $5 \%$ の症例に便潜血が見られた。従来の治療法では便潜血 検查は行っていなかったためステロイドの投与量を増 量したこととの関連は確定できないが, 本治療では点 滴時間も長くより大きなストレスも加わると考えられ る.よって胃部不快感等の腹部症状の出現には十分に 注意を执い，必要に応じて抗潰演剤の早期の投与が望 ましいと考えられる。また糖尿病患者に対しても，本
治療により一時的な血糖上昇はみられるが，必要に応 じたインスリン使用も含め，厳重な管理により特に問 題なく治療可能である。本治療法でのステロイドの総 投与黨は最大でプレドニゾロン約 $1000 \mathrm{mg}$ であり，い わる重度副作用の発現頻度は比較的少ないとさ $れ^{16)}$ ，さらに早期にステロイド投与を中止してもステ ロイド離脱症候群の発生もなかった。

本治療の施行にあたっての最も重要なことは，入院 の上一般的な全身管理を行いながらステロイド大量療 法を開始し，ての後は ENoGを初めとした予後診断を 頻回に行うことによって予後良好と判断されればでき るだけ早期にスデロイド投与を中止することである。 これにより, 高い治療効果と安全性の両立が可能であ ると考える。

iv）ベル麻痺に対する治療方針

もとよりベル麻㾝患者す心゙てにステロイド大量投与 を行う必要はない，当科では顔面神経麻瘁新鮮例の診 察にあたっては，バル麻痺と他の疾患との鑑別診断は 勿論のことであるが, 顔面運動採点, ENoG およびア ブミ骨筋反射 (Stapedius refrex，SR) を中として 治療方針の決定を行っている。すなわち顔面運動が20 点 $/ 40$ 点法以下の重度麻㾇症例は早期に入院の上ステ ロイド大量投与法 (Stennert 法) を開始するが，軽度 麻痺で経過するもの, ENoGが発症約 1 週で40\%以上 に保たれるもの，SR 陽性で経過する例は，神経障害が 軽度であることを示しほぼ1力月で治瘉が見込まれ る ${ }^{17}$.これらの症例に対しては少墨のステロイド内腛 （プロドニゾロン $40 \mathrm{mg} /$ 日程度より溸隇投与）にてま ず経過を観察する。この場合発症ごく早期では，その 後に急速に顔面選動が悪化する症例がみられることも あり，少なくとも発症 1 週までは頻回に経過観察のた めに来院させる。碩面運動の急速な重化がみられれば、 入院のうえStennert法に切り替えて加療を行う。陳旧 例あるいは完全脱神経に楩った症例に対しては，積極 的な治療を行う意味はない、以上のような方針で重症 例を見逃すことなく，早期に治療を行うことが最も肝 要であると考える。

\section{5. 総 括}

i ）ベル麻痺に対するステロイド大量投与

(Stennert 法)の治療効果について検討し, 本治療法 により従来の保存療法に比して治敏率が向上するのみ ならず，治癔に至るまでの期間が大幅に短縮されるこ とが観察された. ENoGの検討からも本治療法の有用 
性が示された。

ii）べル森㫌の病態加らみて, 本治療法の効果は, 発症早期の十分な量のステロイド投与による抗浮腫作 用のためと考光られた。

iii）当科に扔けるべル麻疩の治療方針について述 ベた。

\section{文献}

1) Rothendler $\mathrm{HH}$ : Bell's palsy treated with cortison. J Nerv Ment Dis 114: 346-348, 1951.

2) Stennert $E:$ New concept in the treatment of Bell's palsy. Disorders of the facial nerve. Raven Press, New York. 1982, pp 313-317.

3) Kawai $M$, Inamura $H$, Koike $Y$ et al : On the conservative treatment of Bell's palsy. Acta Otolaryngol (Stockh) Suppl 446: 106-110, 1988.

4) 前山裕之, 稻村博雄, 戸島均, 青楖優, 小池吉郎他: 特発性顔面神経麻㽻に対する, Hydroxyethylstarch 40 を基剤としたステロイド大量投与法の効果. Facial N Res Jpn 10 : 183-186, 1990.

5) Lewis GW: Zoster sine herpete. Brit Med J 2 : 418- 421, 1958.

6) Hilger JA: The nature of Bell's palsy. Laryngoscope 59: 228-235, 1949

7) McGovern FH, Konigsmark BW, Sydnor JB: An immunological concept for Bell's palsy, Laryngoscope 82: 1594-1601, 1972.

8) Tojima $\mathrm{H}$ : Measurement of facial nerve conduction velocity and its application to patients with Bell's palsy. Acta Otolaryngol (Stockh) Suppl 446:3641, 1988.

9）斎藤 修, 戸島 均, 稲村博雄, 青柳 優, 小池吉郎： Collision 法に上る顔面神経伝導速度分布測定の試み. Facial N Res Jpn 9:59-62, 1988.

10）稻村博雄, 小池吉郎, 石川 誠, 外崎 昭: 実験的顔面 神経麻痺に対するステロイド大量投与の効果。日耳鼻 93: 1366-1377, 1990

11）矢沢代四郎，斎藤春雄：顔面神経の变性と膨化。耳舆臨 床 $76: 338-343,1983$.

12) Esslen E: Electromyography and electroneurography, in Fisch $U$ (ed) : Facial Nerve Surgery. Aesculapuis Pub. Co., Birmingham, 1977, pp 93-100.

13）小池吉郎, 稲村博雄: ベル麻暤のステロイド早期大量 投与療法。耳鼻臨床 81：1541-1553，1988.

14）大沢友二, 高圭美津子, 富松正秀, 松浦美保子, 平田考

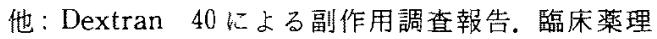
18: 133-134, 1987.

15）小島 端：デネストラン補腹の病理学的研究. 日網会 誌 7:207-219，1967.

16）谷本潔昭：ステロイド剤の副作用,水島 裕 編：ステ ロイド療法の進歩.メヂカルトリビューン,東京, 1985, 143-149頁.

17）稲村博雄, 戸島 均, 青柳 優, 小池吉郎：Bell 麻痺に おけるアブミ骨筋反射一ENoGとの比較検討一：日耳 鼻 $91: 1694 ， 1988$.

(1991年5月29日受稿 1991年8月1日受理)

別刷請求先 テ990-23山形市飯由西2-2-2 山形大学医学部耳鼻咽喉科学教室 稲村博雄 